\title{
Photochemical carbon dioxide reduction with metal complexes: Differences between cobalt and nickel macrocycles
}

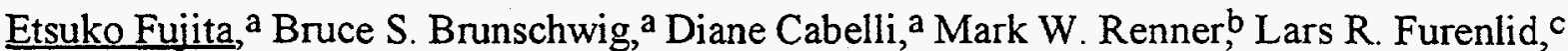
Tomoyuki Ogata, a,d Yuji Wada, ${ }^{\mathrm{d}}$ and Shozo Yanagidad

a Chemistry Department, ${ }^{b}$ Department of Applied Science, and $c$ National Synchrotron Light Source, Brookhaven National Laboratory, Upton, NY 11973-5000, USA, d Material and Life Science, Graduate School of Engineering, Osaka University, Suita, Osaka 565, Japan

\section{INTRODUCTION}

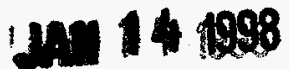

Problems related to increases of green house gases in the atmosphere and the of fossil fuels have made the conversion of $\mathrm{CO}_{2}$ into useful chemicals and fuels an important area of research. However, $\mathrm{CO}_{2}$ reduction poses many scientific challenges. Despite intense interest in photochemical and electrochemical $\mathrm{CO}_{2}$ reduction, the kinetics and mechanism of the reduction remain unclear in many systems.

A number of 14-membered tetraazamacrocyclic complexes serve as catalysts for photochemical and electrochemical $\mathrm{CO}_{2}$ reduction. [ $\left.\mathrm{CoHMD}\left(\mathrm{H}_{2} \mathrm{O}\right)\right]\left(\mathrm{ClO}_{4}\right)_{2}(\mathrm{HMD}=$ $5,7,7,12,14,14$-hexamethyl-1,4,8,11-tetraaza-cyclotetradeca-4,11-diene) ${ }^{1,2}$ and $\mathrm{Ni}$ (cyclam) $\mathrm{Cl}_{2}$ (cyclam $=1,4,8,11$-tetraazacyclotetradecane $)^{3}$ have been used as electrocatalysts for the reduction of $\mathrm{CO}_{2}$ in $\mathrm{H}_{2} \mathrm{O}$ or aqueous $\mathrm{CH}_{3} \mathrm{CN}$. The ratio for $\mathrm{CO} / \mathrm{H}_{2}$ production is $\sim 1$ for [CoHMD $\left.\left(\mathrm{H}_{2} \mathrm{O}\right)\right]\left(\mathrm{ClO}_{4}\right)_{2}$ and $>100$ for $\mathrm{Ni}($ cyclam $) \mathrm{Cl}_{2}$. Metal(I) complexes, metal(III) hydride complexes, and metallocarboxylates such as $\left[\mathrm{Ni}^{\mathrm{III}}(\text { cyclam })\left(\mathrm{CO}_{2}{ }^{2-}\right)\right]^{+}$are postulated as intermediates in the electro- and photo-chemical $\mathrm{CO}_{2}$ reduction. ${ }^{4}$

Our research focuses on mechanistic and kinetic studies of photochemical and electrochemical $\mathrm{CO}_{2}$ reduction that involves metal complexes as catalysts. This work makes use of UV-vis, NMR, and FTIR spectroscopy, flash photolysis, pulse radiolysis, X-ray diffraction, XANES (X-ray absorption near-edge spectroscopy) and EXAFS (extended X-ray absorption fine structure). Here we summarize our research on photochemical carbon dioxide reduction with metal macrocycles.

\section{NATURE OF $\mathrm{Co}-\mathrm{CO}_{2}$ ADDUCTS}

We and others have characterized the interaction of low-spin $\mathrm{d}^{8} \mathrm{CoIHMD}^{+}$with $\mathrm{CO}_{2}$ in $\mathrm{CH}_{3} \mathrm{CN}^{5-9}$ and in $\mathrm{H}_{2} \mathrm{O} .10,11$ Schmidt et al. 12 have characterized the binding thermodynamics as a function of organic solvent. The chiral N-H centers of the macrocycle give rise to two diastereomers, $N$-rac and $N$-meso. The CoL complexes are shown below.

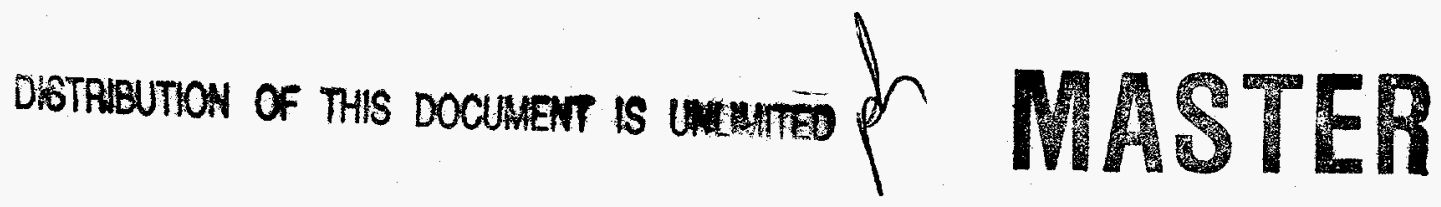


The equilibration between the $\mathrm{N}$-rac- and $\mathrm{N}$-meso cobalt(II) isomers is slow in acidic aqueous and organic media, but equilibration of the two cobalt(I) isomers is relatively rapid $\left(>2 \times 10^{-3}\right.$ $\mathrm{s}^{-1}$ ) in $\mathrm{CH}_{3} \mathrm{CN}$.

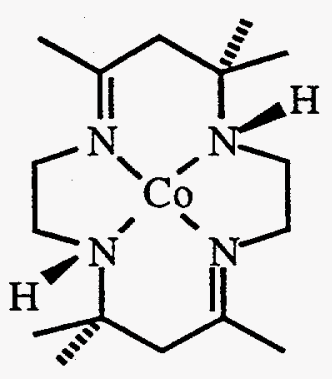

rac HMD

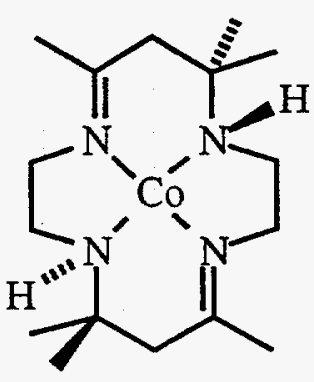

meso HMD

The $\mathrm{CO}_{2}$ binding constants of the corresponding [CoHMD] ${ }^{+}$isomers are quite different: $N$ rac- $[\mathrm{Có} \mathrm{HMD}]^{+},(1.2 \pm 0.5) \times 10^{4} \mathrm{M}^{-1} ; N$-meso- $[\mathrm{CoHMD}]^{+}, 165 \pm 15 \mathrm{M}^{-1.5,6}$ While hydrogen bonding interactions between the bound $\mathrm{CO}_{2}$ and amine protons of the macrocycle will tend to stabilize both adducts, the $N$-meso adduct is destabilized by the steric repulsion by the macrocycle methyl group.

Although the $N$-rac- $\left[\mathrm{CoHMD}\left(\mathrm{CO}_{2}\right)\right]^{+}$adduct decomposes to $\mathrm{N}$-rac-[CoHMD $]^{2+}$ and $\mathrm{CO}$ in wet $\mathrm{CH}_{3} \mathrm{CN},{ }^{5}$ it is stable enough to handle in dry $\mathrm{CH}_{3} \mathrm{CN}$ under a $\mathrm{CO}_{2}$ atmosphere. The complex is thermochromic, 6,7 being purple at room temperature and yellow at low temperature $\left(-100{ }^{\circ} \mathrm{C}\right)$ as shown in Figure 1. The equilibrium between five-coordinate $\left[\mathrm{CoHMD}\left(\mathrm{CO}_{2}\right)\right]^{+}$(purple) and six-coordinate $\left[\mathrm{CoHMD}\left(\mathrm{CO}_{2}\right)\left(\mathrm{CH}_{3} \mathrm{CN}\right)\right]^{+}$(yellow) has been studied by UV-vis, ${ }^{1} \mathrm{H}$ NMR, FT-IR, XANES and EXAFS in $\mathrm{CH}_{3} \mathrm{CN}^{6,7,9}$

$$
\begin{aligned}
& {[\mathrm{CoHMD}]^{+}+\mathrm{CO}_{2} \rightleftharpoons\left[\mathrm{CoHMD}\left(\mathrm{CO}_{2}\right)\right]^{+}} \\
& {\left[\mathrm{CoHMD}\left(\mathrm{CO}_{2}\right)\right]^{+}+\mathrm{CH}_{3} \mathrm{CN} \rightleftharpoons\left[\mathrm{CoHMD}\left(\mathrm{CO}_{2}\right)\left(\mathrm{CH}_{3} \mathrm{CN}\right)\right]^{+}} \\
& \mathrm{K}_{\mathrm{s}}=\left[\mathrm{CoHMD}\left(\mathrm{CO}_{2}\right)\left(\mathrm{CH}_{3} \mathrm{CN}\right)^{+}\right] /\left[\mathrm{CoHMD}\left(\mathrm{CO}_{2}\right)^{+}\right]
\end{aligned}
$$

The singular value decomposition (SVD) ${ }^{13-15}$ spectral analysis of the temperature-dependent UV-vis data between 26 and $-40{ }^{\circ} \mathrm{C}$ is consistent with the presence of two species in $\mathrm{CH}_{3} \mathrm{CN}$. The fit gives $\Delta H^{\circ}=-7.0 \mathrm{kcal} \mathrm{mol}-1$ and $\Delta S^{\circ}=-27 \mathrm{cal} \mathrm{K}^{-1} \mathrm{~mol}^{-1}$ for eq. $2 .^{7}$ The equilibration is rapid on the NMR time scale. The pressure dependence of the equilibrium constant shows that increasing pressure shifts the equilibrium toward the six-coordinate species with an overall reaction volume of $\Delta V^{\circ}=-17.7 \pm 1.0 \mathrm{~mL} \mathrm{~mol}^{-1}$ at $15 \mathrm{C}^{\circ}$ in $\mathrm{CH}_{3} \mathrm{CN}$. ${ }^{16}$ The FT-IR spectra measured over the range 25 to $-75{ }^{\circ} \mathrm{C}$ in $\mathrm{CD}_{3} \mathrm{CN}$ and in a $\mathrm{CD}_{3} \mathrm{CN} / \mathrm{THF}$ mixture indicates ${ }^{7}$ the existence of four $\mathrm{CO}_{2}$ adducts with and without intramolecular hydrogen bonds between the bound $\mathrm{CO}_{2}$ and the amine hydrogens of the ligand: a five-coordinate, nonhydrogen-bonded form $\left(v_{\mathrm{C}}=\mathrm{O}=1710 \mathrm{~cm}^{-1}, v_{\mathrm{NH}}=3208 \mathrm{~cm}^{-1}\right)$, a five-coordinate hydrogenbonded form $\left(v_{\mathrm{C}=0}=1626 \mathrm{~cm}^{-1}\right)$, a six-coordinate non-hydrogen bonded form $\left(v_{\mathrm{C}=0}=1609\right.$ $\left.\mathrm{cm}^{-1}, v_{\mathrm{NH}}=3224 \mathrm{~cm}^{-1}\right)$, and a six-coordinate hydrogen-bonded form $\left(v_{\mathrm{C}=0}=1544 \mathrm{~cm}^{-1}\right.$, $v_{\mathrm{NH}}=3145 \mathrm{~cm}^{-1}$ ). 


\section{DISCLAIMER}

This report was prepared as an account of work sponsored by an agency of the United States Government. Neither the United States Government nor any agency thereof, nor any of their employees, makes any warranty, express or implied, or assumes any legal liability or responsibility for the accuracy, completeness, or usefulness of any information, apparatus, product, or process disclosed, or represents that its use would not infringe privately owned rights. Reference herein to any specific commercial product, process, or service by trade name, trademark, manufacturer, or otherwise does not necessarily constitute or imply its endorsement, recommendation, or favoring by the United States Government or any agency thereof. The views and opinions of authors expressed herein do not necessarily state or reflect those of the United States Government or any agency thereof. 


\section{DISCLAIMER}

Portions of this document may be illegible electronic image products. Images are produced from the best available original document. 


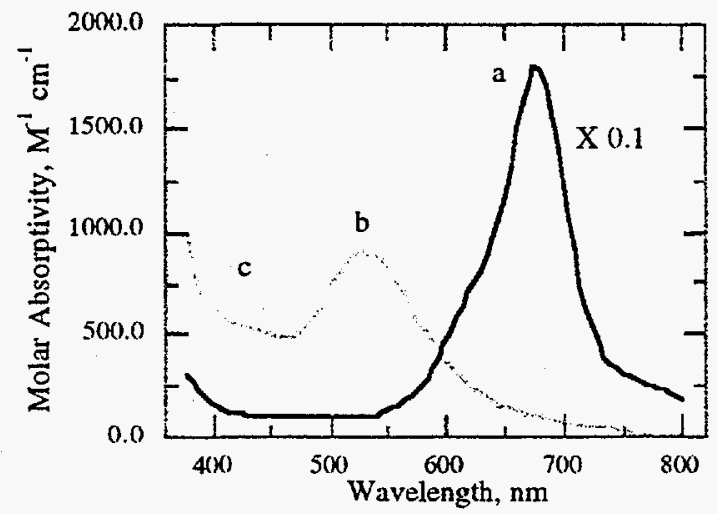

Figure 1. UV-vis spectra of $[\mathrm{Co} \mathrm{HMD}]^{+}(\mathrm{a}),\left[\mathrm{CoHMD}\left(\mathrm{CO}_{2}\right)\right]^{+}$ at room temperature (b), and $\left[\mathrm{Co}^{\mathrm{III}} \mathrm{HMD}\left(\mathrm{CO}_{2}{ }^{2-}\right)\left(\mathrm{CH}_{3} \mathrm{CN}\right)\right]^{+}$ at $-100 \mathrm{C}^{\circ}(\mathrm{c})$ in $\mathrm{CH}_{3} \mathrm{CN}$.

$\mathrm{X}$-ray absorption spectroscopy is an attractive tool for the characterization of metal complexes in solution. The metal coordination number, geometry, and electronic properties can be studied using XANES and the metal-ligand bond distances are obtained through analysis of EXAFS. Previous work ${ }^{17-19}$ has also shown that the edge energy correlates with the oxidation state of the metal. The XANES spectra (Figure 2) for a series of CoHMD complexes ${ }^{9}$ indicate that the edge positions $\left(\mathrm{E}_{0}\right)$ are sensitive to the oxidation state of the metal.
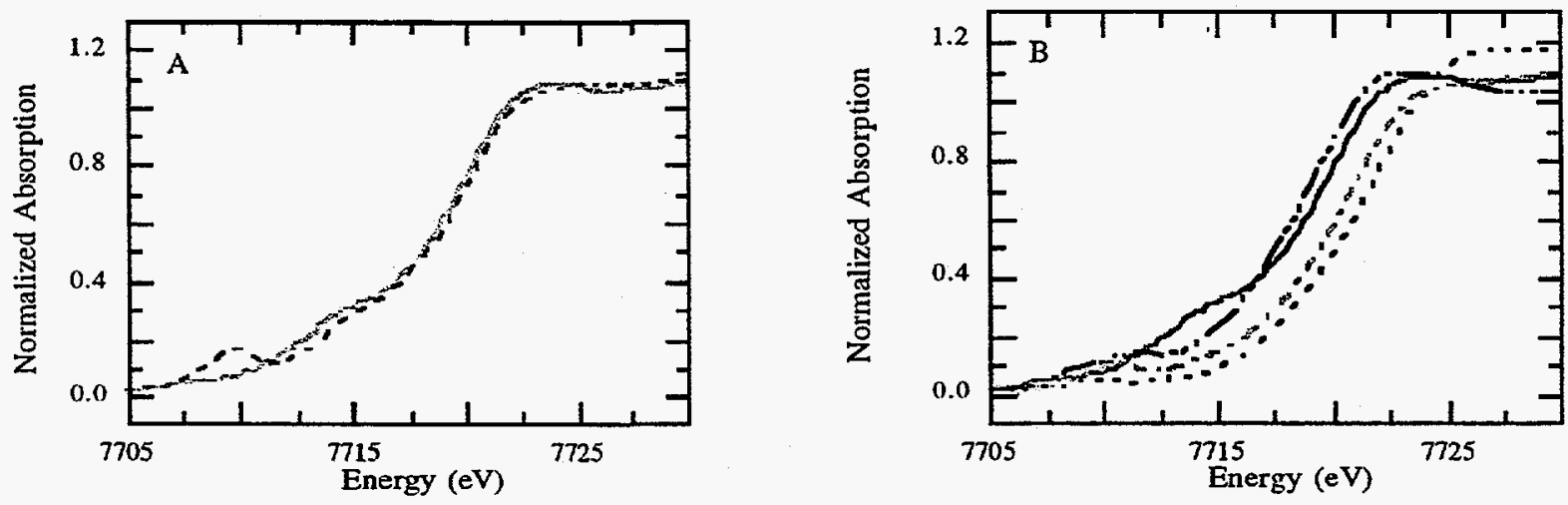

Figure 2. XANES spectra for a series of CoHMD complexes in various oxidation and ligation states. (A) $\left[\mathrm{Co} \Pi_{\mathrm{HMD}}\right]\left(\mathrm{ClO}_{4}\right)_{2}$ in acetonitrile at $150 \mathrm{~K}(\longrightarrow)$, five-coordinate $\left[\mathrm{CoHMD}\left(\mathrm{CO}_{2}\right)\right] \mathrm{ClO}_{4}$ in acetonitrile at room temperature (-.-) (B) $\left[\mathrm{Co} \mathrm{I}_{\mathrm{HMD}}(\mathrm{CO})\right] \mathrm{ClO}_{4}$ in

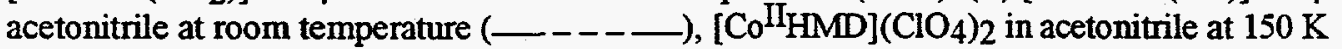
( - ), six-coordinate $\left[\mathrm{CH}_{3} \mathrm{CN}-\mathrm{CoHMD}\left(\mathrm{CO}_{2}\right)\right] \mathrm{ClO}_{4}$ in acetonitrile at $150 \mathrm{~K}(--\longrightarrow)$ and

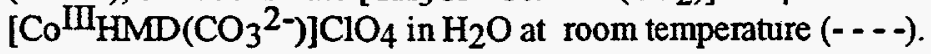


The edge energy, relative to $\left[\mathrm{Co}^{\mathrm{II}} \mathrm{HMD}\right]^{2+}$, decreases $1 \mathrm{eV}$ upon reduction and increases $2 \mathrm{eV}$ upon oxidation. As seen from Figure $2 \mathrm{~A}$, the $\mathrm{E}_{0}$ for five-coordinate $\left[\mathrm{CoHMD}\left(\mathrm{CO}_{2}\right)\right]^{+}$at room temperature is similar to that of [CoII $\mathrm{HMD}]^{2+}$. This is consistent with theoretical predictions ${ }^{20,21}$ that the bound $\mathrm{CO}_{2}$ receives 0.71 electrons mainly from the Co $\mathrm{dz}_{\mathrm{z}}{ }^{2}$ orbital. The six-coordinate $\left[\mathrm{CoHMD}\left(\mathrm{CO}_{2}\right)\left(\mathrm{CH}_{3} \mathrm{CN}\right)\right]^{+}$species shows a $1.2 \mathrm{eV}$ shift towards $\mathrm{Co}(\mathrm{III})$ and is interpreted as a $\mathrm{Co}$ (III)- $\mathrm{CO}_{2}{ }^{2-}$ carboxylate complex. Although the $\mathrm{Co}$ (III) carboxylates have been postulated as intermediates in $\mathrm{CO}_{2}$ reduction and water-gas shift reactions, the XANES results provide the first unambiguous evidence that active metal catalysts, such as [CoIHMD] $]^{+}$, can promote two-electron transfer to the bound $\mathrm{CO}_{2}$ and thereby facilitate its reduction.

\section{PHOTOCHEMICAL $\mathrm{CO}_{2}$ REDUCTION WITH COBALT MACROCYCLES: MECHANISTIC AND KINETIC STUDIES}

Our previous studies indicated that cobalt macrocycles mediate the photoreduction of $\mathrm{CO}_{2}$ to $\mathrm{CO}$ with $p$-terphenyl (TP) as a photosensitizer and a tertiary amine as a sacrificial electron donor in a 5:1 acetonitrile/methanol mixture. ${ }^{22}$ The system enhances the activity of the TP by suppressing the formation of dihydroterphenyl derivatives and produces $\mathrm{CO}$ and formate efficiently with only small amounts of $\mathrm{H}_{2}$. The total quantum yield of $\mathrm{CO}$ and formate is $25 \%$ at $313 \mathrm{~nm}$ in the presence of triethanolamine (TEOA) and Co(cyclam) ${ }^{3+}$.

Transient absorption measurements provide evidence for the sequential formation of the $p$-terphenyl radical anion (TP-), the $\mathrm{CoHMD}^{+}$complex, the $\left[\mathrm{CoHMD}-\mathrm{CO}_{2}\right]^{+}$complex and the $\left[\mathrm{S}-\mathrm{CoHMD}\left(\mathrm{CO}_{2}\right)\right]^{+}$complex $(\mathrm{S}=$ solvent $)$ in the catalytic system containig triethylamine (TEA). ${ }^{23}$ The electron-transfer rate constant $\left(\mathrm{k}_{6}\right)$ for the reaction of TP'- with $\mathrm{Co}^{\Pi} \mathrm{HMD}^{2+}$ is $1.1 \times 10^{10} \mathrm{M}^{-1} \mathrm{~s}^{-1}$ and is probably diffusion controlled because of the large driving force $(\sim 1.1 \mathrm{~V})$. Flash photolysis studies yield a rate constant $\left(\mathrm{k}_{7}\right)$ of $1.7 \times 10^{8} \mathrm{M}^{-1} \mathrm{~s}^{-1}$ and an equilibrium constant of $1.1 \times 10^{4} \mathrm{M}^{-1}$ for the binding of $\mathrm{CO}_{2}$ to $\mathrm{CoHMD}$. These values are consistent with those previously obtained by conventional methods in $\mathrm{CH}_{3} \mathrm{CN} .{ }^{5}$

$$
\begin{aligned}
& \mathrm{TP}^{*}+\mathrm{TEA} \stackrel{\mathrm{k}_{4}}{\longrightarrow} \mathrm{TP}^{-}+\mathrm{TEA}^{+} \\
& \mathrm{TP}^{-}+\mathrm{CO}_{2} \stackrel{\mathrm{k}_{5}}{\longrightarrow} \mathrm{TP}+\mathrm{CO}_{2}^{--} \\
& \mathrm{TP}^{-}+\mathrm{Co}^{\mathrm{II}} \mathrm{HMD}^{2+} \stackrel{\mathrm{k}_{6}}{\longrightarrow} \mathrm{TP}+\mathrm{Co}^{\mathrm{I}} \mathrm{HMD}^{+} \\
& \mathrm{Co}^{\mathrm{I}} \mathrm{HMD}^{+}+\mathrm{CO}_{2} \stackrel{\mathrm{k}_{7}}{\underset{\mathrm{k}_{7}}{2}} \mathrm{Co}^{\mathrm{I}} \mathrm{HMD}\left(\mathrm{CO}_{2}\right)^{+} \\
& \mathrm{Co}^{\mathrm{I}} \mathrm{HMD}\left(\mathrm{CO}_{2}\right)^{+}+\mathrm{S} \underset{\mathrm{k}_{8}}{\stackrel{\mathrm{k}_{8}}{\rightleftharpoons}}\left[\mathrm{SCo}^{\mathrm{I}} \mathrm{HMD}\left(\mathrm{CO}_{2}{ }^{2-}\right)\right]
\end{aligned}
$$




$$
\begin{aligned}
& \mathrm{K}_{\mathrm{CO}_{2}}=\frac{\left[\mathrm{CoHMD}-\mathrm{CO}_{2}\right]}{\left[\mathrm{Co}^{1} \mathrm{HMD}^{+}\right]\left[\mathrm{CO}_{2}\right]} \\
& =\frac{\Delta \mathrm{Abs}}{\mathrm{Abs}_{\infty}\left[\mathrm{CO}_{2}\right]} \\
& {\left[\mathrm{S}-\mathrm{Co}{ }^{\mathrm{IIIHMD}}-\left(\mathrm{CO}_{2}{ }^{2-}\right)\right]^{+}+\mathrm{HA} \rightleftharpoons\left[\mathrm{S}-\mathrm{Co}^{\mathrm{III}} \mathrm{HMD}-(\mathrm{COOH})^{-}\right]^{2+}+\mathrm{A}^{-}} \\
& \mathrm{HA}=\mathrm{TEA}, \mathrm{MeOH}, \mathrm{TEAH}^{+} \\
& {\left[\mathrm{S}-\mathrm{Co}{ }^{\mathrm{IIIHMD}}-(\mathrm{COOH})^{-}\right]^{2+}+\mathrm{e}^{-} \rightarrow \mathrm{Co}^{\mathrm{II}} \mathrm{HMD}^{2+}+\mathrm{CO}+\mathrm{OH}^{-}} \\
& \mathrm{e}^{-}=\mathrm{Col}^{+} \mathrm{Et}_{2} \mathrm{NC}^{\cdot} \mathrm{HCH}_{3}, \mathrm{TP}^{--} \\
& \mathrm{OH}^{-} \pm \mathrm{CO}_{2} \rightleftharpoons \mathrm{HCO}_{3}^{-}
\end{aligned}
$$

The dependence of the decay rate of $\mathrm{TP}^{\circ-}$ on $\left[\mathrm{CO}_{2}\right]$ in the absence of the cobalt macrocycle (eq 5) is not linear. We estimate a rate constant $\mathrm{k}_{5}<10^{6} \mathrm{M}^{-1} \mathrm{~s}^{-1}$ for electron transfer between $\mathrm{TP}^{\circ-}$ and $\left[\mathrm{CO}_{2}\right]$. This rate constant is consistent with the large reorganization energy of the $\mathrm{CO}_{2} / \mathrm{CO}_{2}-$ couple (associated the geometry change from a linear to a bent molecule) ${ }^{24,25}$ and small driving force for the reaction $(0.3 \mathrm{~V})$. Under our photocatalytic conditions the cobalt reacts with the $\mathrm{TP}^{\prime-}>20$ times faster than does the $\mathrm{CO}_{2}$. Thus the direct reduction of $\mathrm{CO}_{2}$ by $\mathrm{TP}^{\prime-}$ plays a negligible role here and all of the photochemically generated reducing equivalents are captured by the cobalt macrocycle.

The production of $\mathrm{CO}$ from $\mathrm{CoL}\left(\mathrm{CO}_{2}\right)^{+}$requires a second reducing equivalent. The source of this equivalent is of interest. Under flash photolysis conditions the TP- has completely reacted before the $\mathrm{CoL}\left(\mathrm{CO}_{2}\right)^{+}$is formed. On the other hand, under continuous photolysis $\mathrm{TP}^{-}-$can react with the $\mathrm{Co}^{I I} \mathrm{~L}^{2+}$ or the $\mathrm{CoL}\left(\mathrm{CO}_{2}\right)^{+}$complexes. In the flash photolysis, where only $\mathrm{Et}_{2} \mathrm{NC}^{\circ} \mathrm{HCH}_{3}$ and/or $\mathrm{Co}^{\mathrm{I}_{2}+}$ may act as the electron donor, the decomposition of $\mathrm{CoLCO}_{2}{ }^{+}$is slow owing to the low concentrations of these two species. In fact, since $\mathrm{CoLCO}_{2}{ }^{+}$decomposes faster with low $\left[\mathrm{CO}_{2}\right]$ (i.e. higher $\left[\mathrm{CoL}^{+}\right]$), $\mathrm{CoL}^{+}$is the likely electron donor under flash photolysis conditions. We suggest that reactions 10-12 are responsible for the production of $\mathrm{CO}$ in the photolysis. The slow step is likely to be the $\mathrm{C}-\mathrm{O}$ bond breakage of the bound carboxylic acid with either $\mathrm{Et}_{2} \mathrm{NC}^{\cdot} \mathrm{HCH}_{3}$, or $\mathrm{Co}^{\mathrm{I}} \mathrm{L}^{+}$acting as electron donor. Unfortunately the UV-vis transient spectrum of $\left[\mathrm{S}-\mathrm{Co}{ }^{I I r} \mathrm{HMD}\left(\mathrm{CO}_{2}{ }^{2-}\right)\right]^{+}$is too weak to study the proton dependence of its disappearance.

\section{PHOTOCHEMICAL $\mathrm{CO}_{2}$ REDUCTION WITH NICKEL MACROCYCLES}

\subsection{Photochemical $\mathrm{CO}_{2}$ reduction}

In contrast to the cobalt-based system, small amounts of $\mathrm{H}_{2}$ and no $\mathrm{CO}$ are produced when nickel cyclam or other saturated 14-membered tetraazamacrocycles (L) in Figure 3 are used to replace the cobalt complex in the above system. ${ }^{22}$ Flash photolysis studies indicate that the electron-transfer rate constant $\left(\mathrm{k}_{13}\right)$ for the reaction of the $p$-terphenyl radical anion with $\mathrm{Ni}^{\mathrm{II}}$ (cyclam) ${ }^{2+}$ is $4.3 \times 10^{9} \mathrm{M}^{-1} \mathrm{~s}^{-1}$. However, when $\mathrm{CO}_{2}$ is added to the solution, the 
decay of the TP anion becomes slower! Flash photolysis studies of the acetonitrile solutions suggest the existence of a minor pathway for $\mathrm{M}^{\mathrm{I}} \mathrm{L}^{+}$formation that does not involve TP. When TEA (or TEOA) is used with UV excitation ( $<320 \mathrm{~nm}$ ), a minor pathway is observed that can be suppressed by the addition of methanol in the case of $\mathrm{CoHMD}^{2+}$, but not $\mathrm{Ni}(\mathrm{cyclam})^{2+}$.

$$
\begin{aligned}
& \mathrm{TP}^{--}+\mathrm{Ni}^{\mathrm{II}} \text { cyclam }^{2+} \stackrel{\mathrm{k}_{13}}{\longrightarrow} \mathrm{TP}+\mathrm{Ni}^{\mathrm{I}} \text { cyclam }^{+} \\
& \mathrm{Ni}^{\mathrm{I} \text { cyclam }}{ }^{+}+\mathrm{CO}_{2} \quad \underset{\mathrm{k}_{14}}{\stackrel{\mathrm{k}_{14}}{\rightleftharpoons}} \mathrm{Ni} \text { cyclam }\left(\mathrm{CO}_{2}\right)^{-1}
\end{aligned}
$$

Both $\mathrm{NiL}^{+}$and $\mathrm{NiL}\left(\mathrm{CO}_{2}\right)^{+}$species are formed under $\mathrm{CO}_{2}$ atmosphere by irradiation at 313 $\mathrm{nm}$ in acetonitrile solutions containing TEA and $\mathrm{NiL}^{2+}$. In order to understand the interesting behavior of these nickel-based systems we have studied the nature of the ground-state complexes, electrochemical $\mathrm{CO}_{2}$ reduction, and the differences in $\mathrm{CO}_{2}$ binding between cobalt and nickel macrocycles.

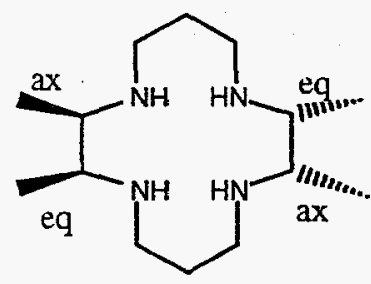

RSSR-HTIM

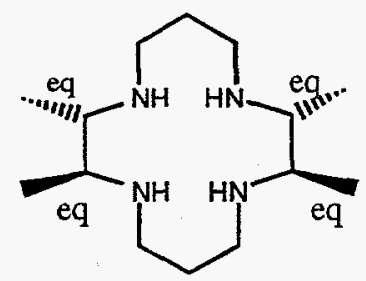

RRSS-HTTM

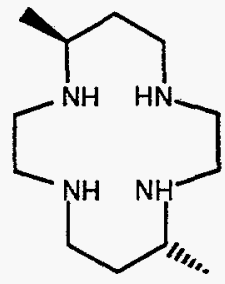

DMC

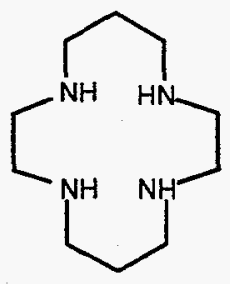

cyclam<smiles>C1CNCCCN2CCCCC2NCCNC1</smiles>

MCC

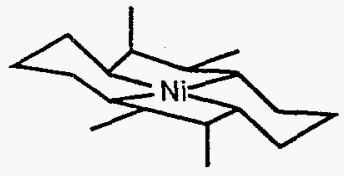

RSSR-HTIM<smiles>C1CC[C@H]2NCCCNCCC[C@H]2NC1</smiles>

MTC

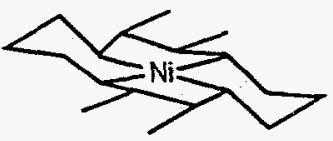

RRSS-HTIM

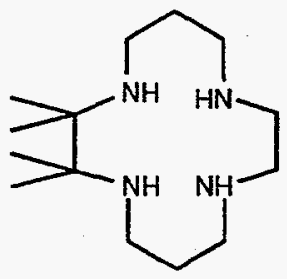

TM

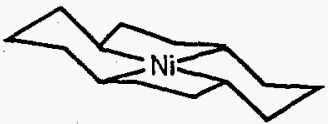

cyclam, Trans III

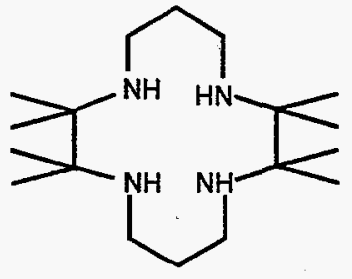

OMC

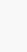




\subsection{Electrochemical $\mathrm{CO}_{2}$ reduction with nickel macrocycles}

The electrocatalytic activity of various nickel macrocycles in aqueous solution were studied. Cyclic voltammograms indicate that $R R S S-\mathrm{NiHTIM}^{2+}, \mathrm{NiMTC}^{2+}$ and $\mathrm{NiDMC}^{2+}$ are better catalysts than $\mathrm{Ni}(\mathrm{cyclam})^{2+}$ in terms of more positive potentials and/or their larger catalytic currents. ${ }^{26}$ Bulk electrolyses with $0.5 \mathrm{mM} \mathrm{Ni}$ complexes confirm that these complexes are excellent catalysts for the selective and efficient $\mathrm{CO}_{2}$ reduction to $\mathrm{CO}$. The macrocycles with equatorial substituents showed increased catalytic activity over those with axial substituents. These structural factors may be important in determining their electrode adsorption and $\mathrm{CO}_{2}$ binding properties.

\subsection{Properties of $\mathrm{Ni}^{\mathrm{II}} \mathrm{L}^{2+}$ complexes}

$\mathrm{Ni}(\text { cyclam })^{2+}$ is oxidized at $0.98 \mathrm{~V}$ and reduced at $-1.45 \mathrm{~V}$ vs $\mathrm{SCE}$ in $\mathrm{CH}_{3} \mathrm{CN}$ under argon. Under a $\mathrm{CO}_{2}$ atmosphere the reduction wave shifts about $10-20 \mathrm{mV}$ more positive, indicating a very small binding constant in $\mathrm{CH}_{3} \mathrm{CN}$. When TEA is added to the solution under argon, the reduction remains at $-1.45 \mathrm{~V}$ as shown in Figure 4. The oxidation potential is not observed due to the oxidation of TEA. The $\mathrm{CV}$ under a $\mathrm{CO}_{2}$ atmosphere shows a reversible oxidation at $0.31 \mathrm{~V}$. The reduction becomes irreversible and occurs at a very negative potential, $-1.8 \mathrm{~V}$ in TEA-containing $\mathrm{CH}_{3} \mathrm{CN}$ (Figure 4). This indicates that the $\left[\mathrm{Ni} \text { (TEA) }\left(\mathrm{CO}_{2}\right)\right]^{+}$adduct is unstable. This also explains the slower decay of $\mathrm{TP}^{-}-$under $\mathrm{CO}_{2}$ atmosphere, since the driving force for electron transfer from the $\mathrm{TP}^{-1}$ to $[\mathrm{NiII}(\text { cyclam })]^{2+}$ becomes smaller upon addition of $\mathrm{CO}_{2}$.

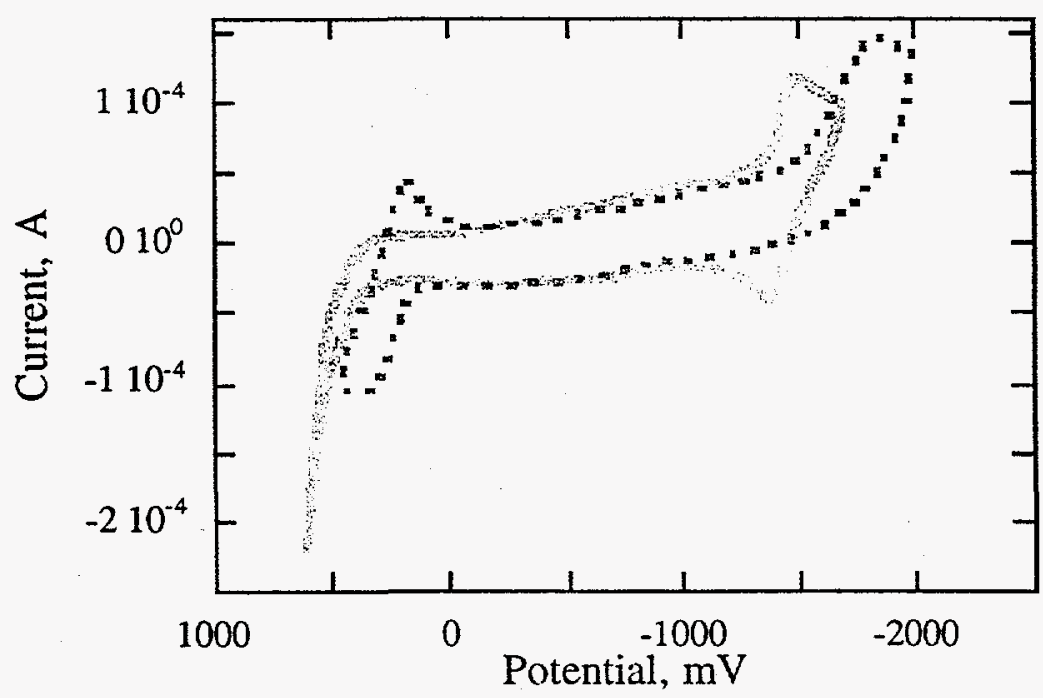

Figure 4. $\mathrm{CV}$ for $1 \mathrm{mM} \mathrm{Ni(cyclam})^{2+}$ with TEA under $\mathrm{Ar}$ (solid) and $\mathrm{CO}_{2}$ (dot) in $\mathrm{CH}_{3} \mathrm{CN}$. 
The reaction of $\mathrm{Ni}{ }^{I I}(\text { cyclam })^{2+}$ with $\mathrm{TEA} / \mathrm{CO}_{2}$ was monitored by $\mathrm{UV}$-vis and $\mathrm{FT}$-IR. The d-d absorption intensity of $\mathrm{NiII}_{\text {(cyclam) }}{ }^{2+}$ decreases with TEA binding in $\mathrm{CH}_{3} \mathrm{CN}$ and shifts to lower energy with $\mathrm{CO}_{2}$ binding in a $\mathrm{TEA}$-containing $\mathrm{CH}_{3} \mathrm{CN}$ solution as shown in Figure 5. Both TEA and $\mathrm{CO}_{2}$ binding are reversible. The IR spectrum of the $\left[\mathrm{Ni}(\text { cyclam })(\mathrm{TEA})\left(\mathrm{CO}_{2}\right)\right]^{2+}$ adduct indicates two kinds of $\mathrm{CO}$ stretching bands at 1615 and $1653 \mathrm{~cm}^{-1}$ due to two isomers (trans $I$ and $I I I$ in Figure 3). With RRSS-NiIHITM ${ }^{2+}$, a single isomer, we observed only one $\mathrm{CO}$ stretching band at $1630 \mathrm{~cm}^{-1}$. We have determined $\mathrm{CO}_{2}$ binding constants for both $\mathrm{Ni}(\mathrm{I})$ and $\mathrm{Ni}(\mathrm{II})$ in $\mathrm{CH}_{3} \mathrm{CN}$. The $\mathrm{CO}_{2}$ binding constant to $\mathrm{Ni}$ (II) cyclam is $1000 \mathrm{M}^{-1}$, much larger than that of $\mathrm{Ni}(\mathrm{I})$. (See below.)
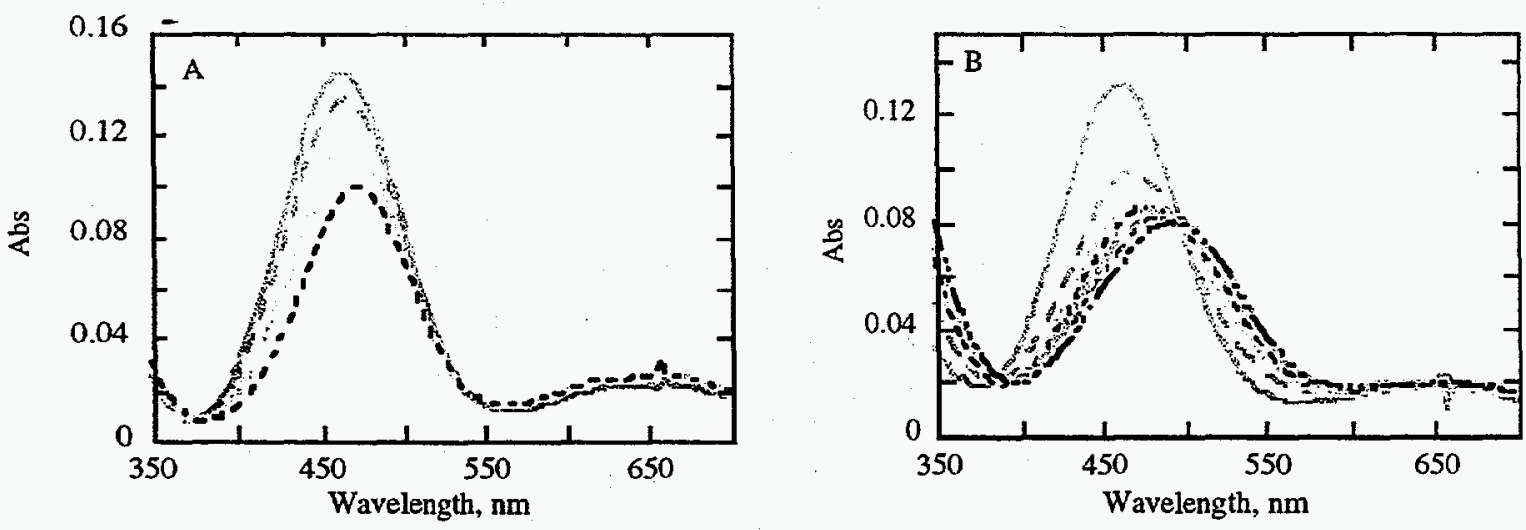

Figure 5. A: Spectral change of $\mathrm{Ni}^{\mathrm{II}}$ (cyclam) ${ }^{2+}$ by the addition of two equivalent of TEA in $\mathrm{CH}_{3} \mathrm{CN}$. $\mathrm{B}$ : Spectral change of $\left[\mathrm{Ni}^{\mathrm{II}} \text { (cyclam)(TEA) }\right]^{2+}$ by the addition of $\mathrm{CO}_{2}$ in a TEA containing $\mathrm{CH}_{3} \mathrm{CN}$.

Table 1 Differences in $\mathrm{CO}_{2}$ binding and $\mathrm{pK}_{\mathrm{a}}$ of $\mathrm{ML}\left(\mathrm{H}^{-}\right)^{2+}$

\begin{tabular}{llccc}
\hline & rac-CoHMD & Ni(cyclam) & RRSS-NiHTIM & NiTM $^{+}$ \\
\hline $\mathrm{K}_{\mathrm{CO}_{2}}$ in $\mathrm{CH}_{3} \mathrm{CN}\left(\mathrm{M}^{-1}\right)$ & $1.2 \times 10^{4}$ & 4 & 4 & $<1$ \\
$\mathrm{~K}_{\mathrm{CO}_{2}}$ in $\mathrm{H}_{2} \mathrm{O}\left(\mathrm{M}^{-1}\right)$ & $4.5 \times 10^{8 \mathrm{a}}$ & $11,16^{\mathrm{b}}$ & 6.0 & $<1$ \\
$\mathrm{k}_{\mathrm{CO}_{2}}$ in $\mathrm{CH}_{3} \mathrm{CN}\left(\mathrm{M}^{-1} \mathrm{~s}^{-1}\right)$ & $1.7 \times 10^{8}$ & $\leq 10^{7}$ & $\leq 10^{7}$ & -- \\
$\mathrm{kCO}_{2}$ in $\mathrm{H}_{2} \mathrm{O}\left(\mathrm{M}^{-1} \mathrm{~s}^{-1}\right)$ & $1.7 \times 10^{8 \mathrm{a}}$ & $3.3 \times 10^{7 \mathrm{~b}}$ & $3 \times 10^{7}$ & -- \\
$\mathrm{pK}_{\mathrm{a}}$ of hydride in $\mathrm{H}_{2} \mathrm{O}$ & $11.4^{\mathrm{a}}$ & $1.8^{\mathrm{b}}$ & 1.9 & $<0.5$ \\
\hline
\end{tabular}

$a$ ref. $11, b$ ref. 28 
This behavior was not observed when $\mathrm{H}_{2} \mathrm{O}$ was used instead of $\mathrm{CH}_{3} \mathrm{CN}$. $\left[\mathrm{Ni}^{\mathrm{II}}(\mathrm{cyclam})\right]^{2+}$ reacts with both TEA (or $\mathrm{OH}^{-}$) and $\mathrm{CO}_{2}$ in $\mathrm{H}_{2} \mathrm{O}$ to form a carbonate-bridged dimer, $\left[(\text { Nicyclam })_{2}\left(\mathrm{CO}_{3}\right)\right]^{2+}$ (UV-vis: 352,548 and $\left.900 \mathrm{~nm} ; v_{\mathrm{CO}_{2}}: 1517,1460,1374 \mathrm{~cm}^{-1}\right)$. The structure was confirmed by an X-ray diffraction study. ${ }^{26}$

$\mathrm{CO}_{2}$ binding constants of $\mathrm{Co}(\mathrm{I})$ and $\mathrm{Ni}(\mathrm{I})$, and the $\mathrm{pK}_{\mathrm{a}}$ of $\mathrm{ML}\left(\mathrm{H}^{-}\right)^{2+}$ are shown in Table 1. As can be seen, the $\mathrm{CO}_{2}$ binding constant for $\mathrm{CoHMD}+$ is much larger than those for the $\mathrm{Ni}$ macrocycles. In $\mathrm{H}_{2} \mathrm{O}$, the binding constants are larger than the corresponding values in $\mathrm{CH}_{3} \mathrm{CN}$. $\mathrm{CO}_{2}$ binding constants for Ni macrocycles are very small, however we see some effect due to ligands. Complexes with axial methyl groups, such as NiTM, show almost no binding of $\mathrm{CO}_{2}$. The trend of the binding constants does not parallel the electrocatalytic activities which is RRSS-NiHTIM ${ }^{2+}>\mathrm{Ni}(\mathrm{cyclam}){ }^{2+}>\mathrm{NiTM}^{2+} .27$ The rate constants for $\mathrm{CO}_{2}$ binding by $\mathrm{CoHMD}{ }^{2+}$ are also about 10 times larger than those by Ni macrocycles. The $\mathrm{pK}_{\mathrm{a}}$ of cobalt hydride is 11.4 , but the corresponding $\mathrm{pK}_{\mathrm{a}}$ values for the nickel macrocycles are less than 2 .

\section{CONCLUDING REMARKS}

$\mathrm{CoHMD}^{2+}$ and $\mathrm{Co}(\text { cyclam })^{2+}$ are good catalysts for photochemical $\mathrm{CO}_{2}$ reduction because of the small $\mathrm{Co}^{\mathrm{II}} \mathrm{L}^{2+} / \mathrm{Co}^{\mathrm{I}} \mathrm{L}^{+}$reorganization energy, the fast $\mathrm{CO}_{2}$ binding to $\mathrm{Co}^{\mathrm{I}} \mathrm{L}^{+}(1.7$ $\times 10^{8} \mathrm{M}^{-1} \mathrm{~s}^{-1}$ ) and the large $\mathrm{K}_{\mathrm{CO}_{2}}$. Our XANES results clearly indicate that active metal catalysts, such as [ $\left.\mathrm{Co}^{\mathrm{I}} \mathrm{HMD}\right]^{+}$, can promote two-electron transfer to the bound $\mathrm{CO}_{2}$ (reduce $\mathrm{CO}_{2}$ to $\mathrm{CO}_{2}{ }^{2-}$ ) and thereby facilitate reduction of $\mathrm{CO}_{2}$. However since $\mathrm{Co}^{\mathrm{I}} \mathrm{L}^{+}$reacts with $\mathrm{H}^{+}$ in $\mathrm{CO}_{2}$ saturated water $(\mathrm{pH} \sim 4)$ the selectivity of $\mathrm{CO}_{2}$ reduction in water is not high.

$\mathrm{NiL}^{2+}(\mathrm{L}=$ cyclam and its derivatives without axial groups $)$ are excellent electrocatalysts for $\mathrm{CO}_{2}$ reduction. It is known that adsorbed $\mathrm{Ni}^{\mathrm{I}^{+}}{ }^{+}$is the active species, however the $\mathrm{CO}_{2}$ binding constants are not known. We find high selectivity for $\mathrm{CO}_{2}$ reduction due to the low $\mathrm{pK}_{\mathrm{a}}$ of the hydride. Ni(cyclam) ${ }^{2+}$ may not be a good photocatalyst

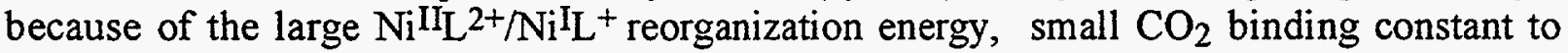
$\mathrm{NiL}^{+}$and instability of the trivalent state. We note that TEA is not an innocent electron donor. It can bind to the nickel center and make the energetics unfavorable for $\mathrm{CO}_{2}$ reduction. The $\mathrm{Ni}(\mathrm{I})$ species is formed by irradiation of the solution containing $\left[\mathrm{Ni}(\mathrm{cyclam})(\mathrm{TEA})_{2}\right]^{2+}$ species at $313 \mathrm{~nm}$ probably due to the intramolecular electron transfer from TEA to Ni.

\section{ACKNOWLEDGMENT}

We thank Drs. Norman Sutin and Carol Creutz for their contribution to earlier work and for their helpful comments. Prof. Rudi van Eldik, Prof. Horst Elias, Prof. Kazuya Kobiro, Ms. Mei Chou, and Dr. David J. Szalda are acknowledged for high pressure work, preparation of $\mathrm{NiHTIM}^{2+}$, preparation of $\mathrm{NiTM}^{+}$, single crystals of $\left[(\mathrm{Ni}(\mathrm{cyclam}))_{2}\left(\mathrm{CO}_{3}\right)\right]^{2+}$, and its structural determination, respectively. We gratefully acknowledge financial support for travel from the Monbusho International Scientific Program: Joint Research (No.07044148). This research was carried out at Brookhaven National Laboratory under contract DE-AC02$76 \mathrm{CH} 00016$ with the U.S. Department of Energy and supported by its Division of Chemical Sciences, Office of Basic Energy Sciences. 


\section{REFERENCES}

1. Fisher, B. \& Eisenberg, R. J. Am. Chem. Soc. 102, 7361 (1980).

2. Tinnemans, A.T.A., Koster, T.P.M., Thewissen, D.H.M.W. \& Mackor, A. Recl. Trav. Chim. Pays. -Bas 103, 288 (1984).

3. Beley, M., Collin, J.-P., Ruppert, R. \& Sauvage, J.-P. J. Am. Chem. Soc. 108, 7461 (1986).

4. Sutin, N., Creutz, C. \& Fujita, E. Comments Inorg. Chem. 19, 67 (1997).

5. Fujita, E., Szalda, D.J., Creutz, C. \& Sutin, N. J. Am. Chem. Soc. 110, 4870 (1988).

6. Fujita, E., Creutz, C., Sutin, N. \& Szalda, D.J. J. Am. Chem. Soc. 113, 343 (1991).

7. Fujita, E., Creutz, C., Sutin, N. \& Brunschwig, B.S. Inorg. Chem. 32, 2657 (1993).

8. Summers, J.S. Ph.D. Thesis, Georgia Institute of Technology, (1989).

9. Fujita, E., Furenlid, L.R. \& Renner, M.W. J. Am. Chem. Soc. 119, 4549-4550 (1997).

10. Creutz, C., Schwarz, H.A., Wishart, J.F., Fujita, E. \& Sutin, N. J. Am. Chem. Soc. 111, 1153 (1989).

11. Creutz, C., Schwarz, H.A., Wishart, J.F., Fujita, E. \& Sutin, N. J. Am. Chem. Soc. 113, 3361 (1991).

12. Schmidt, M.H., Miskelly, G.M. \& Lewis, N.S. J. Am. Chem. Soc. 112, 3420 (1990).

13. Golub, G.H. \& Kahan, W. J. SIAM Numer. Anal., Ser. B 2, 205 (1965).

14. Hofrichter, J., Henry, E.R., Sommer, J. H., Deutsch, R., Ikeda-Saito, M., Yonetani, T. \& Eaton, W. A. Biochemistry 24, 2667 (1985).

15. Shrager, R.I. \& Hendler, R.W. Anal. Chem. 54, 1147 (1982).

16. Fujita, E. \& van Eldik, R. Inorg. Chem. submitted.

17. Manthiram, A., Sarode, P.R., Madhusudan, W.H., Gopalakrishnan, J. \& Rao, C.N.R. J. Phys. Chem. 84, 2200 (1980).

18. Wirt, M.D., Kumar, M., Ragsdale, S.W. \& Chance, M.R. J. Am. Chem. Soc. 115, 2146 (1993).

19. Wirt, M.D., Sagi, I., Chen, E., Frisbie, S. M., Lee, R. \& Chance, M. R. J. Am. Chem. Soc. 113, 5299-5304 (1991).

20. Sakaki, S. \& Dedieu, A. J. Organomet. Chem. 314, C63 (1986).

21. Sakaki, S. \& Dedieu, A. Inorg. Chem. 26, 3278 (1987).

22. Matsuoka, S., Yamamoto, K., Ogata, T., Kusaba, M., Nakashima, N., Fujita, E. \& Yanagida, S. J. Am. Chem. Soc. 115, 601-609 (1993).

23. Ogata, T., Yanagida, S., Brunschwig, B.S. \& Fujita, E. J. Am. Chem. Soc. 117, 6708 (1995).

24. Ovenall, D.W. \& Whiffen, D.H. Mol. Phys. 4, 135 (1961).

25. Chawla, O.P. \& Fessenden, R.W. J. Phys. Chem. 79, 2693 (1975).

26 Fujita, E., Chou, M., \& Szalda, D.J., to be published.

27. Fujita, E., Haff, J., Sanzenbacher, R. \& Elias, H. Inorg. Chem. 33, 4627 (1994).

28 Kelly, C.A., Mulazzani, Q.G., Venturi, M., Blinn, E.L. \& Rodgers, M.A.J., J. Am. Chem. Soc. 117, 4911 (1995) 